AperTO - Archivio Istituzionale Open Access dell'Università di Torino

\title{
Ecophysiological and phytochemical responses of Salvia sinaloensis Fern. to drought stress
}

\section{This is the author's manuscript}

Original Citation:

Availability:

This version is available http://hdl.handle.net/2318/1652777

since 2018-03-22T16:19:59Z

Published version:

DOI:10.1007/s10725-017-0349-1

Terms of use:

Open Access

Anyone can freely access the full text of works made available as "Open Access". Works made available under a Creative Commons license can be used according to the terms and conditions of said license. Use of all other works requires consent of the right holder (author or publisher) if not exempted from copyright protection by the applicable law. 


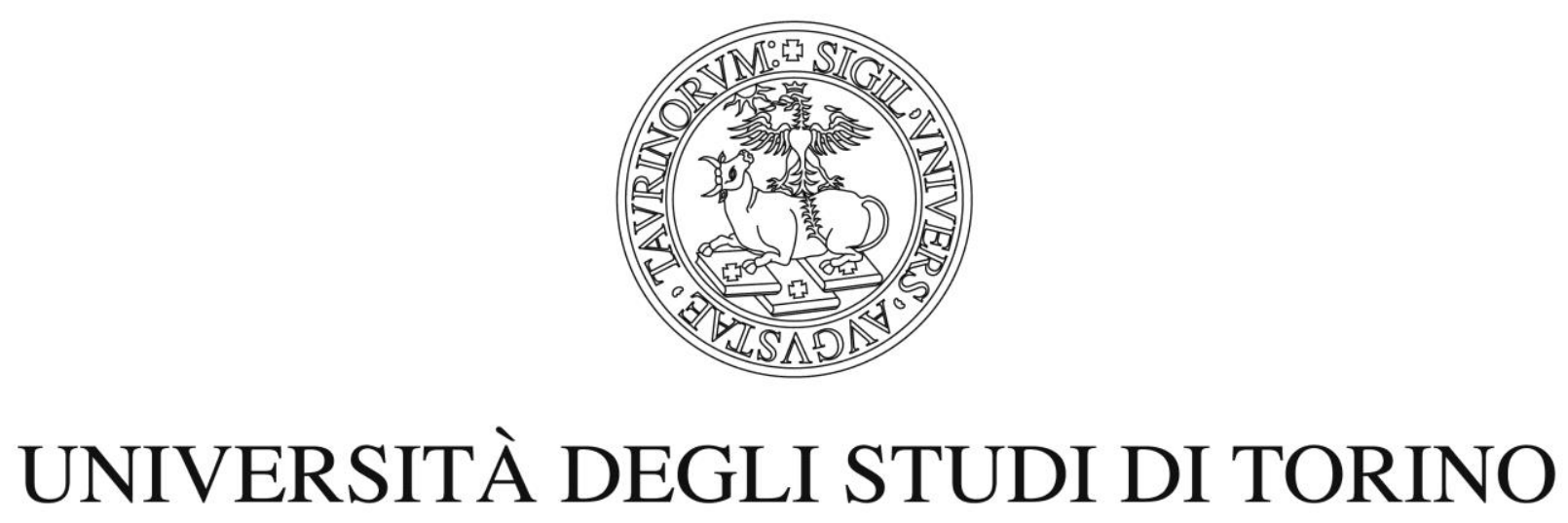

This is an author version of the contribution published on:

Caser M, D’Angiolillo F, Chitarra W, Lovisolo C, Ruffoni B, Pistelli Lu, Pistelli La, Scariot V

Ecophysiological and phytochemical responses of Salvia sinaloensis Fern. to drought stress

PLANT GROWTH REGULATION (2017)

The definitive version is available at:

https://link.springer.com/article/10.1007/s10725-017-0349-1 
1 Ecophysiological and phytochemical responses of Salvia sinaloensis Fern. to drought stress

2

3 Matteo Caser $^{1 *}$, Francesca D'Angiolillo ${ }^{2}$, Walter Chitarra ${ }^{1,5,6}$, Claudio Lovisolo ${ }^{1}$, Barbara 4 Ruffoni $^{3}$, Luisa Pistelli ${ }^{4}$, Laura Pistelli ${ }^{2}$, Valentina Scariot ${ }^{1}$

5

6 'Department of Agricultural, Forest and Food Sciences, University of Torino, Largo Paolo Braccini 2, 7 10095, Grugliasco (TO), Italy.

$8{ }^{2}$ Department of Agriculture, Food, and Environment, University of Pisa, Via del Borghetto 80, 56124, 9 Pisa, Italy.

$10{ }^{3}$ CREA-OF, Ornamental Species Research Unit, Corso degli Inglesi 508, 18038, Sanremo (IM), Italy.

$11{ }^{4}$ Department of Pharmacy, University of Pisa, Via Bonanno 33, 56126, Pisa, Italy.

125 Institute for Sustainable Plant Protection, National Research Council (IPSP-CNR), Strada delle Cacce 13 73, 10135, Torino (TO), Italy.

$14{ }^{6}$ CREA-VE, Viticulture and Enology Research Centre, Viale XXVIII Aprile 26, 31015, Conegliano 15 (TV), Italy.

16

17 *Corresponding author: Matteo Caser, Department of Agricultural, Forest and Food Sciences, 18 University of Torino, Largo Paolo Braccini 2, 10095, Grugliasco (TO), Italy, tel. +390116708935; fax 19 +390116708798; mail: matteo.caser@unito.it 


\section{Abstract}

21 Salvia sinaloensis Fern. (sage) is a medicinal plant containing plant secondary metabolites (PSMs) with antioxidant properties. The current study investigated the effects of drought stress on Salvia sinaloensis morphological and ecophysiological traits, and active constituent production. Sage plants were cultivated in controlled conditions for 34 days and exposed to full irrigation as control, half irrigation, and no irrigation. Changes in growth index (G.I.), dry biomass, leaf water potential (LWP), physiological parameters, active compounds, volatilome (BVOCs) and essential oils (EOs) were determined. Not irrigated plants showed a decrease in total chlorophyll content ( - 14.7\%) and growth (G.I., -59.4\%) from day 18, and dry biomass at day 21 (-56\%), when the complete leaf withering occurred (LWP, -1.10 MPa). Moderate drought stressed plants showed similar trends for chlorophyll content and growth but kept a constant LWP (-0.35 MPa) and dry biomass throughout the experiment, as control plants. Carotenoids were not affected by water regimes. The photosynthetic apparatus tolerated mild to severe water deficits, without a complete stomatal closure. Plants under both stress conditions increased the percentage of phenols and flavonoids and showed altered BVOC and EO chemical profiles. Interestingly Camphor, the main EO oxygenated monoterpene, increased in moderate stressed plants while the sesquiterpene hydrocarbon Germacrene D decreased. The same trend was seen in the headspace under stress severity. The data evidenced a possible role of the active molecules in the response of $S$. sinaloensis plants to drought stress. Taking together, these findings point at S. sinaloensis as a potential drought adaptive species, which could be used in breeding strategies to obtain sages with high quality PSMs, saving irrigation water.

Keywords: Antioxidant activity, BVOCs, Drought stress, EOs, Monoterpenes, Sage

Abbreviations

BVOCs Biogenic volatile organic compounds

45

EOs

Essential pils

46

PSMs

Plant secondary metabolites

47

MAPs

Medicinal and aromatic plants

$48 \mathrm{CC}$

Container capacity

49

LWP

Leaf water potential

Internal $\mathrm{CO}_{2}$ concentration

$51 \quad E$

Transpiration rate 
$52 g_{s}$

$53 \quad A$

54 G.I.

55 FRAP

$56 \mathrm{Fe}^{3+}$-TPTZ

57 SPME

58 GC-EIMS

59 WUE

60 FW

61 DW
Stomatal conductance

Net photosynthetic rate

Growth index

Ferric reducing antioxidant power

Ferric tripyridyl triazine

Solid phase micro extraction

Gas chromatography-electron impact mass spectrometry

Water use efficiency

Fresh weight

Dry weight 


\section{Introduction}

Biogenic volatile organic compounds (BVOCs) and essential oils (EOs) are plant secondary metabolites (PSMs), with important ecological functions within defence, protection, and signalling mechanisms (Loreto and Schnitzler 2010; Raut and Karuppayil 2014). Plants modulate their concentration to withstand stress-related conditions (Fleta-Soriano and Munné-Bosch 2016), such as those provoked by drought (Selmar and Kleinwachter 2013; Kleinwachter et al. 2015). Water deficit affects many aspects of plant physiology and biochemistry, activating root to shoot signalling hydraulic and hormonesmediated processes (Gulen and Eris 2004; Jaleel et al. 2008; Schachtman and Goodger 2008; Pirbalouti et al. 2014; Fleta-Soriano and Munné-Bosch 2016; Ali et al. 2017; Caser et al. 2017). Plants respond by closing their stomata and accumulating compatible solutes to maintain a low water potential and avoid dehydration (Skirycz and Inze 2010). The increased diffusion barrier impairs influx of carbon dioxide $\left(\mathrm{CO}_{2}\right)$ into leaves. In consequence, lower amounts of $\mathrm{CO}_{2}$ are fixed via the Calvin Cycle, and then less reduction equivalents $\left(\mathrm{NADP}^{+}\right)$are available as electron acceptors (Kleinwachter et al. 2015). In this state, all reactions must be promoted to consume $\mathrm{NADPH}+\mathrm{H}^{+}$such as the biosynthesis of highly reduced secondary compounds, i.e. phenols, terpenoids and alkaloids.

BVOCs and EOs are also sources for pharmaceutical, food additives, flavours, and fine chemicals (Zhao et al. 2005). In the last years the global EO production was around 50 to 100 tonnes per annum (Lubbe and Verpoorte 2011; Rauter et al. 2012; Ben Farhat et al. 2013). In medicinal and aromatic plants (MAPs), drought stress enhanced total phenolics and flavonoids production in Labisia pumila Benth. \& Hook. (Jaafar et al. 2012) and monoterpene hydrocarbons and oxygenated sesquiterpenes in Helichrysum petiolare Hilliard \& B.L. (Caser et al. 2016).

Salvia species is well known for possessing numerous secondary metabolites with significant benefits to human nutrition and health, used in folk medicine for a long time and therefore many species were listed in the official Pharmacopoeias. Antiinflammatory and antioxidant properties were observed in leaf extracts of S. officinalis L. (Munné-Bosch et al. 2001), anticonvulsant and sedative properties in leaves and seed extracts of S. leriifolia Benth (Hosseinzadeh and Arabsanavi 2001), and analgesic, neuroprotective and antiparkinson properties in roots of S. miltiorrhiza Bunge (Du and Zhang 2004). However, other Salvia species, such as in S. sinaloensis Fern, had beneficial properties (Abreu et al. 2008) but little information is available.

Despite the enormous richness of MAP species, breeding activities are advanced only for those plants with high demand and cultivation area (e.g. Origanum vulgare L. and Matricaria recutita L.). Wild collection and simple domestication are therefore still the main production strategies (Novak 2017). 
The need of support and speed up MAPs breeding also for minor crops impelled us to deepen the knowledge about S. sinaolensis characteristics in relation to cultivation practices.

In sage, imposed drought stress already proved to increase EOs, total polyphenols content and monoterpenes in S. officinalis (Abreu and Munne-Bosch 2008; Bettaieb et al. 2009; Bettaieb et al. 2011; Radwan et al. 2017) and active constituents in S. miltiorrhiza (Liu et al. 2011).

Here we investigated S. sinaloensis dynamics in response to water limitation through morphological, ecophysiological and phytochemical analyses, contributing to our understanding of the mechanisms underlying plant adaptation and PSMs production.

\section{Materials and methods}

\section{Plant material and treatments}

Three year old plants from the CREA-FSO collection (Code database RGV FAO Salv095, Sanremo,

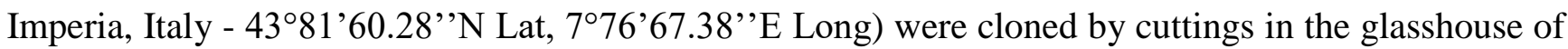
Dept. of Agricultural, Forest and Food Sciences of the University of Torino (Italy, 45 06 ' 23.21 ' 'N Lat, $7^{\circ} 57^{\prime} 82.83^{\prime \prime}$ E Long), and cultivated in vases ( $9 \mathrm{~cm}$ in diameter - one plant per vase) containing peat (Silver Torf, Agrochimica, Bolzano, Italy) and Agriperlite ${ }^{\circledR}$ (70:30), and fertilized with $4 \mathrm{~g} \mathrm{~L}^{-1}$, Osmocote (15:11:13; Scotts Europe, The Netherland). When plants reached $20 \mathrm{~cm}$ in height, one hundred and twenty pots were transferred in a growth chamber at $20{ }^{\circ} \mathrm{C}, 60 \%$ relative humidity and 16 $\mathrm{h}$ photoperiod (constant average PAR of $300 \mu \mathrm{mol} \cdot \mathrm{m}^{-2} \cdot \mathrm{s}^{-1}$ ).

The experimental design was a split-plot design with three treatments and four replications per treatment. Plants were randomly divided in three groups and subjected to irrigation at $100 \%$ of container capacity (CC, control), half of the irrigation volume provided to $\mathrm{CC}$ controls $(50 \% \mathrm{CC}$ - moderate drought stress), or no irrigation ( $0 \% \mathrm{CC})$. The value of $50 \% \mathrm{CC}$ was set to determine moderate drought stress in S. sinaloensis plants in a previous study (Caser et al., 2012). All the water contents were kept constant throughout the experiment. Gravimetric determinations of water contents were made by weighing soil samples before and after oven-drying to constant weight at $80{ }^{\circ} \mathrm{C}$ for one week. These values were used to calibrate all measurements of the moisture content of the substrate in the container. Container capacity was determined $48 \mathrm{~h}$ after irrigation and was calculated according to the equation of Paquin and Mehuys (1980). The soil moisture levels were maintained by manual irrigation and checked by weighting individual container every two days. The experiment lasted for a total of 34 days.

\section{Ecophysiological measurements}


126 Leaf water potential (LWP, $\Psi \mathrm{w})$, internal $\mathrm{CO}_{2}$ concentration $\left(C_{i}\right)$, transpiration rate $(E)$, stomatal 127 conductance $\left(g_{s}\right)$ and net photosynthetic rate $(A)$ were measured twice a week (10-12 a.m.). In each 128 treatment, LWP was counted in three leaves of five plants with a Scholander chamber (Soil Moisture 129 Equipment, Santa Barbara, CA, USA) (Scholander et al. 1965).

$130 \quad C_{i} E, g_{s}$ and $A$ were measured through a gas analyzer ADC-LCPro+ (The Analytical Development 131 Company Ltd, Hoddesdon, UK). For each treatment three apical leaves of five plants were clamped in

132 the leaf chamber, and routines of measurements were performed according to Caser et al. (2016). The $133 \mathrm{CO}_{2}$ concentration $(450-470 \mathrm{ppm})$ and vapour pressure deficit $(19.46 \pm 1.67 \mathrm{~Pa} / \mathrm{KPa})$ were kept constant 134 during the experiment. The ratio between $A$ and $E$ was used to calculate the instantaneous water use 135 efficiency (WUE).

\section{Determination of pigment content}

138 Fifty mg from four fresh fully formed leaves per treatment were used to determine chlorophyll and carotenoids twice a week. After an over-night extraction in $5 \mathrm{ml}$ of methanol at $4{ }^{\circ} \mathrm{C}$ in the dark, pigments were spectrophotometrically determined at 665, 652, and $470 \mathrm{~nm}$ using a Ultrospec 2100 pro (Amersham Biosciences, UK) as described by Lichtenthaler (1987).

The Chlorophyll Meter SPAD-502 (Konica Minolta Sensing Inc., Osaka, Japan) was used to measure the relative quantity of chlorophyll present in five randomly selected leaves per treatment.

\section{Determination of growth index and biomass}

146 Height and diameter of each plant per treatment were measured to calculate the growth index (G.I.;

$147 \Pi^{*}\left\{\left[\left(\mathrm{~W}^{\prime}+\mathrm{W}^{\prime \prime}\right) / 2\right] / 2\right\}^{2 *} \mathrm{H}, \mathrm{W}^{\prime}$ is the broadest diameter, $\mathrm{W}^{\prime \prime}$ is the perpendicular diameter and $\mathrm{H}$ is the 148 height; Hidalgo and Harkess 2002). At day 34, roots and aerial parts of ten plants per treatment were separated and weighed. After recording their fresh biomass, they were oven-dried at $65^{\circ} \mathrm{C}$ for one week and dry biomass was measured.

\section{Determination of phenol and flavonoid content, and antioxidant activity}

153 Fresh leaves (100 mg per treatment) were pulverized and homogenized in a mortar with $1 \mathrm{ml}$ of $70 \%$ $154(\mathrm{v} / \mathrm{v})$ methanol to facilitate the extraction. After 30 minutes of incubation on ice, the extracts were centrifuged at $10.000 \mathrm{~g}$ for 10 minutes at room temperature to collect the supernatant (methanol extract) to be used for the determination of phenol and flavonoid content, and the antioxidant activity. The content of total phenols was measured by using the Folin-Ciocalteau's phenolic method and determined 
as reported by Singleton and Rossi (1965). Twenty $\mu \mathrm{l}$ of methanol extracted samples were added and mixed with $0.5 \mathrm{ml}$ of Folin-Ciocalteau's reagent and $0.45 \mathrm{ml}$ of $7.5 \%(\mathrm{w} / \mathrm{v})$ of saturated sodium carbonate solution. After the incubation at room temperature for $2 \mathrm{~h}$, the absorbance at $765 \mathrm{~nm}$ of the samples was detected in UV-VIS spectrophotometer (Cintra 101, GBC Instruments, Australia).

Total flavonoid content was determined by applying the colorimetric method of Kim et al. (2003). Twenty-five $\mu 1$ of methanolic extract were added to $225 \mu \mathrm{l}$ of distilled water and to $75 \mu \mathrm{l}$ of $5 \%$ $(\mathrm{w} / \mathrm{v})$ sodium nitrite $\left(\mathrm{NaNO}_{2}\right)$. After 5 minutes of incubation were added $75 \mu 1$ of $10 \%$ (w/v) of aluminum trichloride $\left(\mathrm{AlCl}_{3}\right)$ and after 5 minutes were added $500 \mu \mathrm{l}$ of $1 \mathrm{M}$ sodium hydroxide $(\mathrm{NaOH})$. The absorbance of the samples was detected at the UV-VIS spectrophotometer (Cintra 101, GBC Instruments, Australia) after 15 minutes at $415 \mathrm{~nm}$. The quantitative determination was made using a calibration curve with, as standard, quercetin 1:1 (w/v) dissolved in absolute methanol.

The antioxidant activity was determined by using the ferric reducing antioxidant power (FRAP) method with minor modification (Szöllösi and SzőllösiVarga 2002). The FRAP procedure is based on the reduction of a ferric-tripyridyl triazine complex to its ferrous colored form in the presence of antioxidants. An intense blue color complex was formed when ferric tripyridyl triazine ( $\mathrm{Fe}^{3+}$-TPTZ) complex was reduced to the ferrous $\left(\mathrm{Fe}^{2+}\right)$ form and the absorption at $593 \mathrm{~nm}$ was recorded. The calibration curve was plotted with absorbance at $593 \mathrm{~nm}$ versus concentration of $\mathrm{Fe}^{2+}$ solution which in turn plotted against concentrations of standard antioxidant. A total of $50 \mu 1$ samples extract were added to $1.5 \mathrm{ml}$ of the FRAP reagent and mixed well. The absorbance is measured at $593 \mathrm{~nm}$ using UV-VIS spectrophotometer (Cintra 101, GBC Instruments, Australia). Samples are measured in three replicates.

At the end of the experiment, the total amount of total phenols, flavonoids and antioxidant activity per plant (mg/plantFW) was estimated on the basis of the plant fresh biomass.

\section{BVOC analysis}

182

The evaluation of biogenic volatile organic compounds (BVOCs) was conducted at day 14. The headspace of $3 \mathrm{~g}$ of twig was measured by applying a Supelco Solid Phase Micro Extraction (SPME) (Supelco, Bellefonte, PA, USA) with polydimethylsiloxane (PDMS, $100 \mu \mathrm{m}$ ). Each sample was introduced into a $100 \mathrm{ml}$ glass conical flask and equilibrated for $30 \mathrm{~min}$. After the equilibration time, the fiber was exposed to the headspace for $15 \mathrm{~min}$ at room temperature; once sampling was finished the fiber was withdrawn into the needle and transferred to the injection port of the Gas ChromatographyElectron Impact Mass Spectrometry (GC-EIMS) system where the fiber was desorbed. GC-EIMS 
190 equipped with a DB-5 capillary column $(30 \mathrm{~m} \times 0.25 \mathrm{~mm}$; coating thickness $0.25 \mu \mathrm{m})$ and a Varian

191 Saturn 2000 ion trap mass detector chromatograph (Varian, Inc., Palo Alto, CA). Analytical conditions 192 were as follows: injector and transfer line temperature were $250{ }^{\circ} \mathrm{C}$ and $240{ }^{\circ} \mathrm{C}$, respectively; oven 193 temperature was programmed from $60{ }^{\circ} \mathrm{C}$ to $240{ }^{\circ} \mathrm{C}$ at $3{ }^{\circ} \mathrm{C} \mathrm{min}{ }^{-1}$; helium as carrier gas was set at $1 \mathrm{~mL}$

$194 \mathrm{~min}^{-1}$; and the injection was in splitless mode. Identification of the constituents was based on comparison 195 of their retention times with those of authentic samples, and on computer matching against commercial 196 (NIST 98 and ADAMS) and home-made library mass spectra built from pure substances and MS 197 literature data (Swigar \& Silvestein, 1981; Davies, 1990; Adams, 1995).

198 The relative proportions of the volatile constituents were percentages obtained by peak-area 199 normalisation, and all relative response factors were taken as one.

\section{EO analysis}

202 Twenty g of dried leaves were used for the distillation of essential oils (EOs) by using a Clevenger-type 203 apparatus ( 2 h) (Farmacopea Ufficiale della Repubblica Italiana, vol I. IXth edn. Zecca dello Stato: 204 Rome, 1991). The yields of distillation were not determined due to the low amount of the starting plant 205 material. The EOs obtained were solubilized in $n$-hexane, filtered over anhydrous sodium sulphate and 206 stored in a vial at $4{ }^{\circ} \mathrm{C}$ in the dark until use. GC-EIMS was used to analyse all EOs (injection of $0.2 \mu \mathrm{L}$, $20710 \%$ hexane solution) as reported above.

\section{Statistical analysis}

210 Data were previously tested for the variance homogeneity. Ryan-Einot-Gabriel-Welsch-F post-hoc test 211 (REGW-F) $(\mathrm{P}<0.05)$ was applied by means of the SPSS statistical package (version 19.0; SPSS Inc., 212 Chicago. Illinois).

\section{Results and discussion}

\section{Changes in ecophysiological parameters}

216 In this study, moderate drought stress did not affect LWP compared to control (Fig. 1). In both cases it 217 was constant throughout the experiment, with a mean value of $-0.35 \mathrm{MPa}$. On the opposite, no irrigation 218 significantly reduced LWP to -0.64 MPa at day 7. Then, a decreasing trend was observed till day 21 ($2191.10 \mathrm{MPa}$ ) when the complete leaf withering occurred. Within the genus, similar results were found by 220 Eakes et al. (1991) in S. splendens Sellow 'Bonfire' whose leaves reached a LWP ranging between -1.10 221 and -1.40 MPa when exposed to episodic drought (moisture stress conditioned). In other xerophytic sage 
species, drought induced much lower LWP. S. officinalis plants subjected to $50 \% \mathrm{CC}$ and $25 \% \mathrm{CC}$

reached LWP equal to -3.00 and -4.80 MPa, respectively (Bettaieb et al. 2011), and S. mellifera Greene under severe drought condition reached LWP equal to -8.0 MPa, even if severely affected by embolism (Hargrave et al. 1994).

Stomatal closure is the primary mechanism by which plants regulate water loss. It is widely observed that plants reduce stomatal conductance of their leaves in response to declining water potential (Oren et al. 1999). Here, drought did not affect internal $\mathrm{CO}_{2}\left(C_{\mathrm{i}}\right)$ concentration with the exception for the $0 \% \mathrm{CC}$ treatments that led to increase $C_{\mathrm{i}}$ at day 21(Fig. 2A). More differences were found for $E, g s$ and $A$, showing similar trends (Fig. 2B-C-D). Not irrigated plants showed lower values from day 14 , shifted to day 21 (as regarding $g s$ and $A$ ) and from day $25(E)$. At the end of the experiment no differences were observed between control and half irrigation for all measured traits. Thus, drought stress led to partial stomata closure (Fig. 2B). As result, the influx of $\mathrm{CO}_{2}$ is diminished, visible by the strongly decreased rate of photosynthesis in the stressed plants (Fig. 2C) and the lower growth rate (Fig. 3). However, as the stomata closure is not very distinct, the actual $\mathrm{CO}_{2}$ concentration in the stressed plants is not significantly lower than in the controls. Obviously, the steady state concentration, at least in part, is determined by the photosynthetic action (i.e. the affinity of RuBisCO). This is confirmed by the fact that in the severely stressed plants, the internal $\mathrm{CO}_{2}$ concentration increased, when $\mathrm{CO}_{2}$ consumption is stopped due to the lacking photosynthetic activity after 21 days. Results suggested that the photosynthetic apparatus of S. sinaloensis could tolerate mild to severe water deficits and decreasing in photosynthesis couple with reduced stomatal function (Eakes et al. 1991; Galmes et al. 2007).

Instantaneous water use efficiency (WUE, $A / E$ ) is used as an indicator of the water amount applied for growing by plants. Different authors indicated that stressed plants showing higher $A / E$ are more able to utilize energy obtained by photosynthesis per unit of water transpired (Liu and Stützel 2004; Monclus et al. 2006). In this study, drought did not affect WUE except for the 0\% CC treatment at day 21 (Fig. 2E). This finding indicates that S. sinaloensis could efficiently use water resources under moderate and severe drought stress condition at least under control conditions. In many species WUE was improved under water limitation and low gs (Liu et al. 2005). Among these, Trifolium alexandrinum L. (Lazaridou and Koutroubas 2004), Spartina alterniflora Loisel (Hessini et al. 2009), Callistemon (Alvarez et al. 2011), Hybamthus floribundus Lindl. (Kachenko et al. 2011), Rosa hybrida L. (Cai et al. 2012), Vitis vinifera L. 'Grenache' and ‘Tempranillo' (Lovisolo et al. 2010; Medrano et al. 2015), and Helichrysum petiolare (Caser et al. 2016). In sage, Lambrecht et al. (2011) observed that leaf physiological activity of $S$. mellifera was not limited by imposed water deficits as well as indicated in 
our study. The photosynthetic apparatus was not completely affected by drought stress also in $S$.

splendens 'Bonfire' (Eakes et al. 1991) and in S. pitcheri L. (Hamerlynck et al. 1997), highlighting the positive water use efficiency attitude of different species within the genus Salvia.

257

\section{Changes in chlorophyll, carotenoids and plant growth}

The decrease of chlorophyll and carotenoids in drought stressed plants is reported by several authors (Kaminska-Rozek and Pukacki 2004; Pastenes et al. 2005; Guerfel et al. 2009). Here, moderate and severe drought stress reduced the total chlorophyll content starting from day 18 up to the end of the experiment (Supplementary Table 1), while carotenoids and Chl:Car ratios were not affected by the imposed irrigation regimes. Plants of S. officinalis treated with 50\% CC and 25\% CC presented similar values and trends (Bettaieb et al. 2011). Similarly, a chlorophyll decrease was observed also in plants of Catharanthus roseus L. (Jaleel et al. 2008) and Helichrysum petiolare (Caser et al. 2016). Jaleel et al. (2009) indicated that carotenoids play an important role in protecting different processes from reactive oxygen species damages. Here, the presence of constant amount of carotenoid during the experiment suggests a possible role to cope with oxidative damages. Similar results were observed by Caser et al. (2016) in $H$. petiolare plants subjected to $50 \% \mathrm{CC}$ water regime.

The evaluation of SPAD units by the use of the chlorophyll meter is commonly used to associate leaf damages and abiotic stresses (Caser et al., 2013) and leaf photosynthesis (Castelli et al. 1996). Here, no significant results were highlighted (data not shown). Similarly, Caser et al. (2012) showed no differences of SPAD values in S. dolomitica Codd and S. sinaloensis plants under drought conditions with the exception for those irrigated with $20 \%$ CC in which was observed an increase.

The decrease of chlorophyll content might cause a reduction in growth parameters of plants under water stress conditions (Viera et al. 1991). In this study, all the treated plants grew similarly till day 11 (Fig. 3). Then, drought stressed plants significantly reduced their growth. Not irrigated plants reached the lowest G.I. at day $21\left(2654.00 \mathrm{~cm}^{3}\right)$, while plants under 50\% CC kept constant G.I. from day 18 onward, ranging between $6908.73 \mathrm{~cm}^{3}$ and $5686.40 \mathrm{~cm}^{3}$. These results are in agreement with a preliminary study on S. sinaloensis plants treated with different irrigation regimes where irrigation with $20 \% \mathrm{CC}$ and $40 \% \mathrm{CC}$ significantly reduced the plant growth compared to $80 \% \mathrm{CC}$ and controls (Caser et al. 2012). However, as shown in Table 1, here only severe drought stress reduced drastically the total dry mass of plants (-56\%), affecting particularly the roots (-67\%). Thus, the R:A ratio (-55\%), favoring the shoot as showed in other species under severe drought stress conditions (Comas et al. 2013; Caser et al. 2016). A reduction of shoot dry weight, leaf area, stem length and root length was similarly seen in 
S. splendens (Eakes et al. 1991; Burnett et al. 2005). On the opposite, half irrigated plants showed an increase in root dry biomass $(+14 \%)$ and consequently in R:A ratio $(+37 \%)$ compared to control. Since roots are the only source to acquire water from soil, the root growth, its density, proliferation and size are key responses of plants to drought stress (Kavar et al. 2007). The drought tolerance of tea, onion and cotton was increased by improved root growth and root functioning (Farooq et al. 2009).

\section{Changes in phenols and flavonoids and antioxidant activity}

Polyphenols and flavonoids are among the most adaptable PSMs, helping plants to cope with different stress conditions (Di Ferdinando et al. 2014). In this study the total content of phenols in full-irrigated plants decreased during the whole experiment, reaching the lowest value between days 21 and 25 (0.98 $\mathrm{mg} / \mathrm{g} \mathrm{FW}$ ) (Fig. 4A). Conversely, at the same data point moderate stressed plants exhibited the highest amounts (14.26 mg/g FW and $13.16 \mathrm{mg} / \mathrm{g} \mathrm{FW}$ at the days 21 and 25, respectively). A different behavior was also observed in severe stressed plants, that showed higher content of phenols from day 11 to day 18 with the highest value at day $11(15.74 \mathrm{mg} / \mathrm{g} \mathrm{FW})$. A similar dynamic was observed for the total flavonoids accumulation (Fig. 4B). In control plants, flavonoids increased during the first 7 days of cultivation. Subsequently, they dramatically decreased reaching minimum values between days 21 (1.19 $\mathrm{mg} / \mathrm{g} \mathrm{FW})$ and $25(1.16 \mathrm{mg} / \mathrm{g} \mathrm{FW})$. By contrast, in moderate stress condition flavonoid content kept constant until day 21, later increased with higher values from day 18 till the end of the experiment, reaching the maximum content at day $25(2.89 \mathrm{mg} / \mathrm{g} \mathrm{FW})$. In the not irrigated plants, the total content of flavonoids peaked at day $11(3.73 \mathrm{mg} / \mathrm{g} \mathrm{FW})$. In literature, different works showed that in drought stressed plants was observed an increase in secondary metabolites content. Plants of Prunus persica L., Echinacea purpurea L., Hypericum brasiliense Choisy, Trachyspermum ammi L. and Labisia pumila Benth. \& Hook. subjected to drought stress showed significant increase in total phenols (Kubota et al. 1988; Gray et al. 2003; de Abreu and Mazzafera 2005; Azhar et al. 2011; Jaafar et al. 2012) and Pisum sativum in flavonoids (Nogués et al. 1998). In Salvia officinalis, an increase in phenols was observed in half irrigated plants (Bettaieb et al. 2011). Here, a mid to late increase in total phenols and flavonoids occurred in plants subjected to 50\% CC. According with Paulsen and Selmar (2016), imposed drought stress generally results in decrease of aerial biomass gain and the corresponding dry or fresh weight are strongly influencing the content of natural products in MAPs. Here, as indicated in Table 2, moderate drought conditions resulted in a significant increase of the total content of phenols in comparison to severe drought stressed plants and controls (16.44, 22.85 and $10.43 \mathrm{mg} / \mathrm{plant}$ in 100\% CC, 50\%CC and 
stress and control conditions $(6.42,6.47$ and $2.73 \mathrm{mg} / \mathrm{plantFW}$ of flavonoids in $100 \% \mathrm{CC}, 50 \% \mathrm{CC}$ and $0 \% \mathrm{CC}$, respectively). These findings should be taken in consideration for future industrial purposes. (Munné-Bosch and Penuelas 2003). Plant resistance to ROS is associated with an increase in antioxidant activity to prevent stress damage (Bor et al. 2003). In this study, only plants under $50 \%$ CC showed a significant increase of antioxidant activity at the end of the experiment (Fig. 4C). Similarly, at the end of the experiment the total amount of antioxidant activity per plant was much superior in moderate drought stressed plants than the others $(106.37,125.98$ and $20.86 \mathrm{mg} / \mathrm{plantFW}$ in $100 \% \mathrm{CC}, 50 \% \mathrm{CC}$ and $0 \% \mathrm{CC}$, respectively) (Table 2). These findings confirm the ability of this plant to encounter the water limitation $(50 \% \mathrm{CC})$ activating stress defense signaling and pathways respect to severe drought stress $(0 \% \mathrm{CC})$ where metabolic and physiological constraints are not able to allow plant survival.

\section{Changes in emitted BVOCs}

Different authors observed that any stress factor can potentially change the rate of volatile release and alter the bouquet of BVOCs (Dicke and Baldwin 2010; Holopainen and Gershenzon 2010; Niinemets et al. 2013). Their emission can vary drastically depending on the species, organ, developmental stage and environmental conditions (Holopainen and Gershenzon 2010). Abiotic stress can enhances the emission of BVOC rates and patterns by the alteration of the communication with other organisms and photochemical cycles (Loreto and Schnitzler 2010). In the present study, the volatiles emitted and identified from the analyzed twigs are reported in Supplementary Table 2. In total a number of 20, 32 and 38 compounds were recognized in plants treated with full irrigation, half irrigation and no irrigation, respectively, accounting for $92.1 \%, 96.6 \%$ and $95.4 \%$ of the total compositions, respectively. The volatile fractions were characterized mainly by sesquiterpene hydrocarbons (sh) although a mild reduction by increasing stress conditions was observed $(57.5 \%<42.8 \%<42.7 \%$ in full irrigation, half irrigation and no irrigation, respectively). No irrigation affected the production of four of the six reported volatile molecule classes. In particular, an increase in oxygenated monoterpenes (om) $(9.7 \%, 16.2 \%$ and $23.6 \%$ in full irrigation, half irrigation and no irrigation, respectively), was observed. Among the other categories not-terpene derivates (nt), oxygenated sesquiterpene (os) and apocarotenoids (ac) were observed only in few percentage. However, plants under $50 \% \mathrm{CC}$ exhibited the highest content in monoterpene hydrocarbons $(\mathrm{mh})(24.2 \%, 37.1 \%$ and $22.0 \%$ in full irrigation, half irrigation and no irrigation, respectively). All investigated headspaces showed different array of the main constituents. 
$\beta$-Pinene, in moderate stressed plants by $\beta$-Pinene $>$ Camphor $>\beta$-Caryophyllene and in severe stressed

plants by $\beta$-Caryophyllene $>$ Camphor $>\beta$-Pinene. Among the various constituents, a very sharp decrease (4.4 times) was observed for the Germacrene D (from $22.0 \%$ to $5.0 \%$ in full irrigation and no irrigation, respectively). On the opposite the oxygenated monoterpene Camphor increased 2.5 times when plants were subjected to $0 \% \mathrm{CC}$.

The literature is ambiguous concerning BVOC emission in relation to water availability. Several recent reviews addressed the roles of BVOCs in enhancing the tolerance of plants to various general abiotic stressors (Holopainen and Gershenzon 2010; Loreto and Schnitzler 2010; Possell and Loreto 2013; Rinnan et al. 2014). In particular, under drought Mediterranean climatic condition, the emission of oxygenated monoterpene is common (Loreto et al. 2014) and is thought to promote direct and indirect defense by modulating the signaling that biochemically activates defense pathways in response to stressful conditions (Loreto and Schnitzler 2010; Rinnan et al. 2014). Pistelli et al. (2013) reported an increase in oxygenated monoterpenes in Salvia officinalis plants under in vitro growing conditions. Moreover, there is evidence that the strength of the emission of BVOCs can be quantitatively related to the severity of abiotic stresses (Niinemets et al. 2013). As reported by Niinemets et al. (2004) the emission of oxygenated BVOCs depends on stomatal behavior. The stomatal closure in response to drought stress is therefore expected to drastically affect the emission of these compounds as showed in Quercus ilex L. (Bertin and Staudt 1996; Llusia and Peñuelas 1998; Loreto et al. 2001). Here, on the contrary we observed an increase in oxygenated monoterpenes under mild and severe drought stress associated with a not completely stomatal closure. Progressing soil water deficiency enhanced monoterpene emissions also in Pinus halepensis Mill. and Cistus albidus L., whereas did not affect it in Rosmarinus officinalis L. and Quercus coccifera L. (Ormeño et al. 2007). By contrast, overall emissions of sesquiterpenes were reduced by water deficiency in all the four species (Ormeño et al. 2007). Moreover, Hansen et al. (1997) and Ormeño et al. (2007) noticed that monoterpene emission in $R$. officinalis was not dependent by photosynthesis, but may originate from "de novo" synthesis in the photosynthetic tissues (Steinbrecher et al. 1999; Ormeño et al. 2009; Nogués et al. 2015). Taking together, all these results on BVOCs could represent important findings for studying the plantenvironment interactions and can be used in breeding strategies to improve volatile compounds yield and quality.

\section{Changes on essential oil}


In a wide range of experiments was highlighted that plants under drought stressed showed an increase in secondary metabolites content (Selmar and Kleinwächter 2013). Here, a total of 78 constituents were detected in the investigated EOs of which 59, 41 and 62 in full, half and not irrigated plants, respectively (Supplementary Table 3). Drought stress conditions only slightly increased the total number of constituents identified in the EOs (94.0, 99.6 and 98.8\% at full irrigation, half irrigation and no irrigation, respectively). Similar results were observed in Satureja hortensis L. (Baher et al. 2002), Lippia berlandieri Schauer (Dunford and Vazquez 2005), Petroselinum crispum (Mill.) (Petropoulos et al. 2008), S. officinalis (Bettaieb et al. 2009), and Laurus nobilis L. (Maatallah et al. 2016) plants treated with similar drought stressed conditions. Regarding the type of constituents, moderate drought stress increased the total amount of monoterpenes (both oxygenated monoterpenes and monoterpene hydrocarbons: 51.5, 77.1 and 54.9\% and 1.4, 6.0 and 1.9\% in full irrigation, half irrigation and no irrigation, respectively) and deeply reduced the oxygenated sesquiterpenes (29.2, 6.3 and $26.9 \%$ in full irrigation, half irrigation and no irrigation, respectively). Similarly, imposed moderate drought stress strongly increased (2 to 4 fold) the content of Camphor, a specific compound in the essential oil, as also reported in S. officinalis plants (Bettaieb et al. 2009; Nowak et al. 2010) and in Picea abies L. and Pinus silvestris L. (Turtola et al. 2003). Nowak et al. (2010) reported that moderate stressed condition resulted in a massive increase of concentration of monoterpenes compensating the reduction in biomass. In fact, the stimulation to produce high terpene content under drought stress could be due to the low allocation of carbon to the growth, suggesting a trade-off between growth and defense (Turtola et al. 2003).

The main constituent of EOs in all the studied plants was Camphor (an oxygenated monoterpene). This constituent strongly increased under 50\% CC (36.5, 62.8, 38.7\% in full irrigation, half irrigation 402 and no irrigation, respectively). Our results showed a chemical profile composed by Camphor > Caryophyllene oxide $>\alpha$-Cadinol in $100 \% \mathrm{CC}$; Camphor $>\beta$-Caryophyllene $>$ Borneol in 50\% CC; and by Camphor > Caryophyllene oxide > $\beta$-Caryophyllene in 0\% CC. Abreu et al. (2008) reported interesting antioxidant properties of $S$. sinaloensis due to the presence of phenolic diterpenes in 406 comparison with S. officinalis extracts. In the present study, moderate drought stress application induced an increase in oxygenated monoterpenes that are generally the most active components in many EOs (Ruberto and Baratta 2000; Imanshahidi and Hosseinzadeh 2006), such as in S. cinnabarina L. with hypotensive effect (Alfieri et al. 2007), S. dolomitica with anti-bacterial activity (Kamatou et al. 2007) and in S. officinalis with antifungal and anti-inflammatory activity on mammalian cells (Abu-Darwish et al. 2013). These results may contribute to a good utilization of S. sinaloensis EOs for plant breeding and pharmaceutical applications. 


\section{Conclusions}

415 Drought is one of the abiotic stresses that most severely affects plant growth and development. 416 Consequently, plants adjust their structure, metabolism and function to withstand it. Generally, it is 417 characterized by reduction of water content and leaf water potential, turgor loss, closure of stomata and 418 decrease in cell enlargement and growth. However, with respect to MAPs, the water shortage can lead 419 to an enhancement of the content of PSMs, Our results showed that in S. sinaloensis drought affects 420 morphological, ecophysiological and chemical traits depending on the stress severity. Plant growth 421 parameters and chlorophyll were generally reduced but the photosynthetic apparatus demonstrated to 422 tolerate moderate to severe drought conditions, without a complete stomatal closure. Interestingly, under 423 moderate stressed conditions, monoterpene hydrocarbons increased in both BVOCs and Eos (e.g. 424 camphene), while volatile oxygenated monoterpenes increased still with increasing stress severity (e.g. 425 camphor). Thus, drought stress did not inhibit per se the biosynthesis of monoterpenes, even better the 426 highest BVOCs and EOs contents were obtained in moderate drought stress condition. Furthermore, this 427 stress condition induced a mid to late increase in phenols, flavonoids and antioxidant activity, suggesting 428 that active molecule accumulation is associated with drought tolerance.

429 In conclusion, here an integrated approach, combining metabolomic and physiological studies, 430 allowed us to get new insights in mechanisms and processes involved in S. sinaloensis adaptation to 431 drought stress and PSMs production. Coupling this information, breeders and industries may optimize 432 MAPs breeding and cultivation, in order to produce high quality plant materials adopting sustainable 433 cultivation techniques.

434

\section{Acknowledgments}

436 This research was partially funded by the INTERREG-ALCOTRA 2007-2013 Project "AROMA" (n. 437 68). Authors acknowledged Claudio Cervelli and Paolo Lo Turco for plant furnishing and multiplication. 


\section{References}

Abreu ME, Müller M, Alegre L, Munné-Bosch S (2008) Phenolic diterpene and $\alpha$-tocopherol contents in leaf extracts of 60 Salvia species. J Sci Food Agric 88:2648-2653

Abreu ME, Munné-Bosch S (2008) Salicylic acid may be involved in the regulation of drought-induced leaf senescence in perennials: a case study in field-grown Salvia officinalis L. plants. Env Exp Bot 64:105-112

Abu-Darwish MS, Cabral C, Ferreira IV, Gonçalves MJ, Cavaleiro C, Cruz MT, Al-bdour TH, Salgueiro L (2013) Essential oil of common sage (Salvia officinalis L.) from Jordan: Assessment of safety in mammalian cells and its antifungal and anti-inflammatory potential. Biomed Res Int 2013: 538940

Adams RP (1995) Identification of essential oil components by gas chromatography-mass spectroscopy. Carol Stream, IL: Allured.

Alfieri A, Maione F, Bisio A, Romussi G, Mascolo N, Cicala C (2007) Effect of a diterpenoid from Salvia cinnabarina on arterial blood pressure in rats. Phyt Res 21:690-692

Ali F, Bano A, Fazal A (2017) Recent methods of drought stress tolerance in plants. Plant Growth Regul 82:363-375

Alvarez S, Navarro A, Nicolas E, Sanchez-Blanco MJ (2011) Transpiration, photosynthetic responses, tissue water relations and dry mass partitioning in Callistemon plants during drought conditions. Sci Hortic 129(2):306-312

Azhar N, Hussain B, Ashraf MY, Abbasi KY (2011) Water stress mediated changes in growth, physiology and secondary metabolites of desi ajwain (Trachyspermum ammi L.). Pak J Bot 43:15-19

Baher ZF, Mirza M, Ghorbanli M, Rezaii MB (2002) The influence of water stress on plant height, herbal and essential oil yield and composition in Satureja hortensis L. Flavour Frag J 17:275277

Ben Farhat M, Landoulsi A, Chaouch-Hamada R, Sotomayor JA, Jordán MJ (2013) Characterization and quantification of phenolic compounds and antioxidant properties of Salvia species growing in different habitats. Ind Crop Prod 49:904-914

Ben Taarit M, Msaada K, Hosni K, Hammami M, Kchouk ME, Marzouk B (2009) Plant growth, essential oil yield and composition of sage (Salvia officinalis L.) fruits cultivated under salt stress conditions. Ind Crops Prod 30:333-337 
Bertin N, Staudt M (1996) Effect of water stress on monoterpene emissions from young potted holm oak (Quercus ilex L.) trees. Oecologia 107:456-462

Bettaieb I, Zakhama N, Aidi Wannes W, Kchouk ME, Marzouk B (2009) Water deficit effects on Salvia officinalis fatty acids and essential oils composition. Sci Hortic 120:271-275

Bettaieb I, Hamrouni-Sellami I, Bourgou S, Limam F, Marzouk B (2011) Drought effects on polyphenol composition and antioxidant activities in aerial parts of Salvia officinalis L. Acta Physiol Plant 33:1103-1111

Bor M, Özdemir F, Türkan I (2003) The effect of salt stress on lipid peroxidation and antioxidants in leaves of sugar beet Beta vulgaris L. and wild beet Beta maritima L. Plant Sci 164:77-84

Bretzel F, Benvenuti S, Pistelli L (2014) Metal contamination in urban street sediment in Pisa (Italy) can affect the production of antioxidant metabolites in Taraxacum officinale Weber. Environ Sci Pollut Res 21:2325-2333

Burnett SE, Pennisi SV, Thomas PA, van Iersel MW (2005) Controlled drought affects morphology and anatomy of Salvia splendens. J Amer Soc Hort Sci 130:775-781

Cai X, Starman T, Niu G, Hall C, Lombardini L (2012) Response of selected garden rose to drought stress. HortSci 47:1050-1055

Caser M, Ruffoni B, Scariot V (2012) Screening for drought tolerance in Salvia spp. and Helichrysum petiolare: a way to select low maintenance ornamental plants. Acta Hortic 953:239-246

Caser M, Scariot V, Gaino W, Larcher F, Devecchi M (2013) The effects of sodium chloride on the aesthetic value of Buxus spp. Europ J Hortic Sci 78:153-159

Caser M, D’Angiolillo F, Chitarra W, Lovisolo C, Ruffoni B, Pistelli Lu, Pistelli La, Scariot V (2016) Water deficit trigger changes in valuable physiological and phytochemical parameters in Helichrysum petiolare Hilliard \& B.L. Burtt. Ind Crops Prod 83:680-692

Caser M, Lovisolo C, Scariot V (2017) The influence of water stress on growth, ecophysiology and ornamental quality of potted Primula vulgaris 'Heidy' plants. New insights to increase water use efficiency in plant production. Plant Growth Regul DOI 10.1007/s10725-017-0301-4

Castelli F, Contillo R, Miceli F (1996) Non-destructive determination of leaf chlorophyll content in four crop species. J Agr Crop Sci 4:275-283

Comas L, Becker S, Cruz VMV, Byrne PF, Dierig DA (2013) Root traits contributing to plant productivity under drought. Front Plant Sci 4:442

Davies NW (1990) Gas chromatographic retention indexes of monoterpenes and sesquiterpenes on methyl silicone and carbowx20M phases. J Chrom 503:1-24 
501 de Abreu IN, Mazzafera P (2005) Effect of water and temperature stress on the content of active 502 constituents of Hypericum brasiliense Choisy. Plant Physiol Biochem 43(3):241-248

503 di Ferdinando M, Brunetti C, Agati G, Tattini M (2014) Multiple functions of polyphenols in plants 504 inhabiting unfavorable Mediterranean areas. Env Exp Bot 103:107-116

505 Dicke M, Baldwin IT (2010) The evolutionary context for herbivore-induced plant volatiles: beyond the $506 \quad$ 'cry for help'. Trends Plant Sci 15:167-175

507 Du GH, Zhang JT (2004) The general situation and progress of the modern research of red sage root 508 (Radix Salviae miltiorrhizae). II. Yiyao Daobao 23:435-440

509 Dunford NT, Vazquez RS (2005) Effect of water stress on plant growth and thymol and carvacrol 510 concentrations in Mexican oregano grown under controlled conditions. J Appl Hortic 7:20-22

511 Eakes DJ, Wright RD, Seiler JR (1991) Moisture stress conditioning effects on Salvia splendens 512 'Bonfire'. J Amer Soc Hort Sci 116:716-719

513 Farmacopea Ufficiale della Repubblica Italiana, 9th Edt, Istituto Poligrafico Zecca dello Stato, Roma $514 \quad$ (1991)

515 Farooq M, Wahid A, Kobayashi N, Fujita D, Basra SMA (2009) Plant drought stress: effects, 516 mechanisms and management. Agr Sust Develop 29:185-212

517 Fleta-Soriano E, Munné-Bosch S (2016) Stress memory and the inevitable effects of drought: a $518 \quad$ physiological perspective. Front Plant Sci 7:143

519 Galmés J, Medrano H, Flexas J (2007) Photosynthetic limitations in response to water stress and 520 recovery in Mediterranean plants with different growth forms. New Phytol 175:81-93

521 Gray DE, Pallardy SG, Garrett HE, Rottinghaus G (2003) Acute drought stress and plant age effects on 522 alkamide and phenolic acid content in purple coneflower roots. Planta Med 69:50-55

523 Guerfel M, Baccouri O, Boujnah D, Chaibi W, Zarrouk M (2009) Impacts of water stress on gas 524 exchange, water relations, chlorophyll content and leaf structure in the two main Tunisian olive 525 (Olea europaea L.) cultivars. Sci Hortic 119:257-263

526 Gulen H, Eris A (2004) Effect of heat stress on peroxidase activity and total protein content in strawberry 527 plants. Plant Sci 166:739-744

528 Hamerlynck EP, McAllister CA, Knapp AK, Ham JM, Owensby CE (1997) Photosynthetic gas 529 exchange and water relation responses of three tallgrass prairie species to elevated carbon dioxide $530 \quad$ and moderate drought. Int J Plant Sci 158:608-616 
531 Hansen U, van Eijk J, Bertin N, Staudt M, Kotzias D, Seufert G, Fugit JL, Torres L, Cecinato A, 532 Brancaleoni E, Ciccioli P, Bomboi T (1997) Biogenic emissions and $\mathrm{CO}_{2}$ gas exchange 533 investigated on four Mediterranean shrubs. Atmosp Env 31:157-166

534 Hargrave KR, Kolb KJ, Ewers FW, Davis SD (1994) Conduit diameter and drought-induced embolism 535 in Salvia mellifera Greene (Labiatae). New Phytol 126:695-705

536 Hessini K, Martinez JP, Gandour M, Albouchi A, Soltani A, Abdelly C (2009) Effect of water stress on 537 growth, osmotic adjustment, cell wall elasticity and water-use efficiency in Spartina alterniflora. $538 \quad$ Env Exp Bot 67:312-319

539 Hidalgo PR, Harkess RL (2002) Earthworm castings as a substrate for Poinsettia production. HortSci 540 37:304-308

\section{3}

Holopainen JK, Gershenzon J (2010) Multiple stress factors and the emission of plant VOCs. Trends Plant Sci 15:176-184

Hosseinzadeh H, Arabsanavi J (2001) Anticonvulsant effect of Salvia leriifolia Benth. Seed and leaf extracts in mice. Iran J Basic Med Sci 3:163-170

Imanshahidi M, Hosseinzadeh H (2006) The pharmacological effects of Salvia species on the central nervous system. Phytother Res 20:427-437

Jaafar HZE, Ibrahim MH, Fakri NFM (2012) Impact of soil field water capacity in secondary metabolites, phenylalanine ammonia-lyase (PAL), maliondialdehyde (MDA) and photosynthetic responses of Malaysian kacip Fatimah (Labisia pumila Benth). Molecules 17:7305-7322

Jaleel CA, Gopi R, Sankar B, Gomathinayagam M, Panneerselvam R (2008) Differential responses in water use efficiency in two varieties of Catharanthus roseus under drought stress. C R Biologies $331: 42-47$

Jaleel CA, Manivannan P, Wahid A, Farooq M, Somasundaram R, Panneerselvam R (2009) Drought stress in plants: a review on morphological characteristics and pigments composition. Int J Agric. Biol 11:100-105

Kachenko AG, Bhatia N, Singh B (2011) Influence of drought stress on the nickel-hyperaccumulating shrub Hybanthus floribundus (Lindl.) F. Muell. Subsp. floribundus. Int J Plant Sci 172(3):315322

Kamatou GPP, Van Vuuren SF, Van Heerden FR, Seaman T, Viljoen AM (2007) Antibacterial and antimycobacterial activities of South African Salvia species and isolated compounds from $S$. chamelaegnea. South Afr J Bot 73:552-557 
562 Kaminska-Rozek E, Pukacki PM (2004) Effect of water deficit on oxidative stress and degradation of cell membranes in needles of Norway spruce (Picea abies (L.) Karst.). Acta Physiol Plant 26:431-442

Kavar T, Maras M, Kidric M, Sustar-Vozlic J, Meglic V (2007) Identification of genes involved in the response of leaves of Phaseolus vulgaris to drought stress. Mol Breed 21:159-172

Kim DO, Jeong SW, Lee CY (2003) Antioxidant capacity of phenolic phytochemicals from various 568 cultivars of plums. Food Chem 81(3):321-326

Kramer PJ, Boyer JS (1995) Water relations of plants and soils. Academic Press, New York

570

571

572

573

574

575

576

577

578

579

580

581

582

583

584

585

586

587

588

589

590

591

Kleinwächter M, Paulsen J, Bloem E, Schnug E, Selmar D (2015) Moderate drought and signal transducer induced biosynthesis of relevant secondary metabolite in thyme (Thymus vulgaris), greater celandine (Chelidonium majus) and parsley (Petroselinum crispum). Ind Crops Prod 64:158-166

Kubota N, Mimura H, Shimamura K (1988) The effects of drought and flooding on the phenolic compounds in peach fruits. Sci Rep Fac Agric Okayama Univ 171:17-21

Lambrecht SC, Santiago LS, DeVan CM, Cervera JC, Stripe CM, Buckingham LA, Pasquini SC (2011) Plant water status and hydraulic conductance during flowering in the southern California coastal sage shrub Salvia mellifera (Lamiaceae). Am J Bot 98:1286-1292

Lazaridou M, Koutroubas SD (2004) Drought effect on water use efficiency of berseem clover at various growth stages. In: New directions for a diverse planet: Proceedings of the $4^{\text {th }}$ International Crop Science Congress Brisbane, Australia (Vol. 26)

Lichtenthaler HK (1987) Chlorophylls and carotenoids: pigments of photosynthetic biomembranes. Meth Enzymol 148:350-382

Liu F, Stützel H (2004) Biomass partitioning, specific leaf area, and water use efficiency of vegetable amaranth (Amaranthus spp.) in response to drought stress. Sci Hortic 102:15-27

Liu F, Andersen MN, Jacobsen SE, Jensen CR (2005) Stomatal control and water use efficiency of soybean (Glycine max L. Merr.) during progressive soil drying. Env Exp Bot 54:33-40

Liu H, Wang X, Wang D, Zou Z, Liang Z (2011) Effect of drought stress on growth and accumulation of active constituents in Salvia miltiorrhiza Bunge. Ind Crops Prod 33:84-88

Llusia J, Peñuelas J (1998) Changes in terpene content and emission in potted Mediterranean woody plants under severe drought. Can J Bot 76:1366-1373 
592 Loreto F, Fischbach RJ, Schnitzler JP, Ciccioli P, Brancaleoni E, Calfapietra C, Seufer G (2001) 593 Monoterpene emission and monoterpene synthase activities in the Mediterranean evergreen oak

Loreto F, Schnitzler JP (2010) Abiotic stresses and induced BVOCs. Trends plant Sci 15:154-166

Loreto F, Dicke M, Schnitzler JP, Turlings TCJ (2014) Plant volatiles and the environment. Plant Cell Env 37:1905-1908

Lovisolo C, Perrone I, Carra A, Ferrandino A, Flexas J, Medrano H, Schubert A (2010) Drought-induced changes in development and function of grapevine (Vitis spp.) organs and in their hydraulic and non hydraulic interactions at the whole plant level: a physiological and molecular update. Funct Plant Biol 37:98-116

Lubbe A, Verpoorte R (2011) Cultivation of medicinal and aromatic plants for specialty industrial materials. Ind Crops Prod 34:785-801

Maatallah S, Nasri N, Hajlaoui H, Albouchi A, Elaissi A (2016) Evaluation changing of essential oil of laurel (Laurus nobilis L.) under water deficit stress conditions. Ind Crops Prod 91:170-178

Medrano H, Tomas M, Martorell S, Flexas J, Hernandez E, Rossello J, Pou A, Escalona JM, Bota J (2015) From leaf to whole-plant water use efficiency (WUE) in complex canopies: limitations of leaf WUE as a selection target. Crop J 3(3):220-228

Monclus R, Dreyer E, Villar M, Delmotte FM, Delay D, Petit JM, Barbaroux C, Thiec D, Bréchet C, Brignolas $F$ (2006) Impact of drought on productivity and water use efficiency in 29 genotypes of Populus deltoides $\times$ Populus nigra. New Phytol 169:765-777

Munné-Bosch S, Mueller M, Schwarz K, Alegre L (2001) Diterpenes and antioxidative protection in drought-stressed Salvia officinalis plants. J Plant Physiol 11:1431-1437

Munné-Bosch S, Peñuelas J (2003) Photo- and antioxidative protection, and a role for salicyclic acid during drought and recovery in field-grown Phillyrea angustifolia plants. Planta 217:758-766

Niinemets Ü, Loreto F, Reichstein M (2004) Physiological and physicochemical controls on foliar volatile organic compound emissions. Trends Plant Sci 9:180-186

Niinemets Ü, Kännaste A, Copolovici L (2013) Quantitative patterns between plant volatile emissions induced by biotic stresses and the degree of damage. Front Plant Sci 4:262

Nogués S, Allen DJ, Morison JIL, Baker NR (1998) Ultraviolet-B radiation effects on water relations, leaf development, and photosynthesis in droughted pea plants. Plant Physiol 117:173-181

Nogués I, Muzzini V, Loreto F, Bustamante MA (2015) Drought and soil amendment effects on monoterpene emission in rosemary plants. Sci Total Envi 538:768-778 
624 Novak J (2017) Letter to the Editor on "How to implement GACP of MAPs? A practical implementation 625 guide to Good Agricultural and Wild Collection Practices (GACP)”. J Appl Res Med Arom Plants http://dx.doi.org/10.1016/j.jarmap.2016.12.003

Nowak M, Kleinwächter M, Manderscheid R, Weigel HJ, Selmar D (2010) Drought stress increases the accumulation of monoterpenes in sage (Salvia officinalis), an effect that is compensated by elevated carbon dioxide concentration. J Appl Bot Food Qual 83:133-136

Oren R, Sperry JS, Katul GG, Pataki DE, Ewers BE, Phillips N, Schäfer KVR (1999) Survey and synthesis of intra- and interspecific variation in stomatal sensitivity to vapour pressure deficit. Plant Cell Env 22:1515-1526

Ormeño E, Mévy JP, Vila B, Bousquet Mélou A, Greff S, Bonin G, Fernandez C (2007) Water deficit stress induces different monoterpene and sesquiterpene emission changes in Mediterranean species. Relationship between terpene emissions and plant water potential. Chemosphere 67:276284

Ormeño E, Romain O, Mevy JP, Baldy V, Fernandez C (2009) Compost may affect volatile and semivolatile plant emissions through nitrogen supply and chlorophyll fluorescence. Chemosphere 77:94-104

Paquin R, Mehuys GR (1980) Influence of soil moisture on cold tolerance of alfalfa. Can J Plant Sci 60:139-147

Pastenes C, Pimentel P, Lillo J (2005) Leaf movements and photoinhibition in relation to water stress in field-grown beans. J Exp Bot 56:425-433

Paulsen J, Selmar D (2016) The difficulty of correct reference values when evaluating the effects of drought stress: a case study with Thymus vulgaris. J Appl Bot Food Qual 89:287-289

Petropoulos SA, Daferera D, Polissiou MG, Passam HC (2008) The effect of water deficit stress on the growth, yield and composition of essential oils of parsley. Sci Hortic 115:393-397

Pirbalouti AG, Samani MR, Hashemi M, Zeinali H (2014) Salicylic acid affects growth, essential oil and chemical compositions of thyme (Thymus daenensis Celak.) under reduced irrigation. Plant Growth Regul 72:289-301

Pistelli L, Noccioli C, D’Angiolillo F, Pistelli L (2013) Composition of volatile in micropropagated and field grown aromatic plants from Tuscany Islands. Acta Bioch Polon 60:43-50

Possell M, Loreto F (2013) The role of volatile organic compounds in plant resistance to abiotic stresses: responses and mechanisms. In: Biology, Controls and Models of Tree Volatile Organic Compound Emissions (Eds Ü. Niinemets, RK Monson), pp. 209-235. Springer, Berlin, Germany 
656 Radwan A, Kleinwachter M, Selmar D (2017) Impact of drought stress on specialised metabolism: 657 Biosynthesis and the expression of monoterpene synthases in sage (Salvia officinalis). 658 Phytochemistry 141:20-26

659 Raut JS, Karuppayil SM (2014) A status review on the medicinal properties of essential oils. Ind Crops $660 \quad$ Prod 62:250-264

661 Rauter AP, Dias C, Martins A, Branco I, Neng NR, Nogueira JM, Goulart M, Silva FVM, Justino J, 662 Trevitt C, Waltho JP (2012) Non-toxic Salvia sclareoides Brot. extracts as a source of functional 663 food ingredients: phenolic profile, antioxidant activity and prion binding properties. Food Chem $664 \quad 132: 1930-1935$

665 Rinnan R, Steinke M, McGenity T, Loreto F 2014. Plant volatiles in extreme terrestrial and marine 666 environments. Plant Cell Env 37:1776-1789

667 Ruberto G, Baratta MT (2000) Antioxidant activity of selected essential oil components in two lipid 668 model systems. Food Chem 69:167-174

669 Schachtman DP, Goodger JQD (2008) Chemical root to shoot signaling under drought. Trends Plant Sci $670 \quad 13: 281-287$

671 Scholander PF, Hammel HT, Bradstreet ED, Hemmingsen EA (1965) Sap pressure in vascular plants. $672 \quad$ Negative hydrostatic pressure can be measured in plants. Science 148:339-346

673 Selmar D, Kleinwachter M (2013) Influencing the product quality by deliberately applying drought 674 stress during the cultivation of medicinal plants. Ind Crops Prod 42:558-666

675 Singleton VL, Rossi JAJ (1965) Colorimetry of total phenolics with phosphomolybdic-phosphotungstic 676 acid reagent. Amer J Enol Viticol 16:144-158

677 Skirycz A, Inzé D (2010) More from less: plant growth under limited water. Curr Opin Biotech 21_197678 203

680

Steinbrecher F, Hauff K, Hakola H, Rössler J (1999) A revised parameterization for emission modeling of isoprenoids for boreal plants. In: Laurilla T, Lindfors V (Eds,), BiogenicVOC Emissions and Phytochemistry in the Boreal Regions of EuropeAir Pollution Research Report 70. Commission of European Communities. Luxembourg, pp. 29-43

686

Swigar AA, Silverstein RM (1981) Monoterpenes. Aldrich Chem. Comp., Milwaukee

Szôllôsi R, Szôllôsi Varga I (2002) Total antioxidant power in some species of Labiatae (adaptation of FRAP method). Acta Biol Szegediensis 46:125-127

Turtola S, Manninen A, Rikal R, Kainulainen P (2003) Drought stress alters the concentration of wood terpenoids in scots pine and Norway spruce seedling. J Chem Ecol 29:1981-1995 
688 Viera HJ, Bergamaschi H, Angelocci LR, Libardi PL (1991) Performance of two bean cultivars under 689 two water availability regimes. II. Stomatal resistance to vapour diffusion, transpiration flux 690 density and water potential in the plant (in Portugal) Pesquisa Agropecu Bras 9:1035-1045

691 Zhao J, Davis LC, Verpoorte R (2005) Elicitor signal transduction leading to production of plant 692 secondary metabolites. Biotech Adv 23:283-333 


\section{Tables}

\section{Table 1}

695 Aerial and root dry mass accumulation and root:aerial (R:A) ratio of Salvia sinaloensis plants under full 696 irrigation ( $100 \%$ container capacity, CC), half irrigation $(50 \%$ CC), or no irrigation (0\% CC). In brackets 697 are reported the percentage variations referred to controls.

\begin{tabular}{lllll}
\hline \multirow{2}{*}{ Water regime } & \multicolumn{2}{l}{ Dry mass accumulation (gDW/plant) } & \multirow{2}{*}{ R:A ratio } \\
\cline { 2 - 5 } & Total & Aerial part & Root & \\
\hline $100 \% \mathrm{CC}$ & $3.57 \mathrm{a}(100 \%)$ & $1.06 \mathrm{a}(100 \%)$ & $2.51 \mathrm{a}(100 \%)$ & $2.37 \mathrm{~b}(100 \%)$ \\
$50 \% \mathrm{CC}$ & $3.75 \mathrm{a}(105 \%)$ & $0.88 \mathrm{ab}(83 \%)$ & $2.87 \mathrm{a}(114 \%)$ & $3.26 \mathrm{a}(137 \%)$ \\
$0 \% \mathrm{CC}$ & $1.59 \mathrm{~b}(44 \%)$ & $0.77 \mathrm{~b}(73 \%)$ & $0.82 \mathrm{~b}(33 \%)$ & $1.06 \mathrm{c}(45 \%)$ \\
\hline$P$ & $* *$ & $*$ & $* *$ & $*$
\end{tabular}

698 The statistical relevance of 'Between-Subjects Effects' tests $\left({ }^{*}=P<0.05,{ }^{* *}=P<0.001, \mathrm{~ns}=\right.$ not significant $)$. Mean values showing the same letter are not 699 statistically different at $P \leq 0.05$ according to the REGW-F test.

700

\section{$701 \quad$ Table 2}

702 Total amount (mg/plantFW) of phenols, flavonoids and antioxidant activity at the end of the experiment 703 in Salvia sinaloensis plants under full irrigation (100\% container capacity, CC), half irrigation (50\% $704 \mathrm{CC})$, or no irrigation (0\% CC). In brackets are reported the percentage variations referred to controls.

\begin{tabular}{llll}
\hline \multirow{2}{*}{ Water regime } & \multicolumn{2}{l}{ Total amount $(\mathrm{mg} / \mathrm{plantFW})$} \\
\cline { 2 - 4 } & Total phenols & Flavonoids & Antioxidant activity \\
\hline $100 \% \mathrm{CC}$ & $16.44 \mathrm{~b}(100 \%)$ & $6.42 \mathrm{a}(100 \%)$ & $106.37 \mathrm{~b}(100 \%)$ \\
$50 \% \mathrm{CC}$ & $22.85 \mathrm{a}(139 \%)$ & $6.47 \mathrm{a}(101 \%)$ & $125.98 \mathrm{a}(118 \%)$ \\
$0 \% \mathrm{CC}$ & $10.43 \mathrm{c}(63 \%)$ & $2.73 \mathrm{~b}(43 \%)$ & $20.86 \mathrm{c}(20 \%)$ \\
\hline $\mathrm{P}$ & $* *$ & $*$ & $*$
\end{tabular}

705 The statistical relevance of 'Between-Subjects Effects' tests $\left({ }^{*}=P<0.05,{ }^{* *}=P<0.001, \mathrm{~ns}=\right.$ not significant). Mean values showing the same letter are not 706 statistically different at $P \leq 0.05$ according to the REGW-F test. 


\section{Figure captions}

708 Fig. 1 Dynamics of leaf water potential (LWP) of Salvia sinaloensis plants treated with full irrigation 709 (100\% container capacity, CC - black line), half irrigation (50\% CC - dark grey line), or no irrigation 710 (0\% CC - light grey line). Means superscripted by the same letter do not differ significantly, according 711 to REGW-F post-hoc test (NS = non significant).

712

713 Fig. 2 Gas exchange (internal $\mathrm{CO}_{2}$ concentration, $C_{\mathrm{i}}$ - A; transpiration rate, $E$ - B; stomatal conductance, $714 g_{s}-\mathrm{C}$; net photosynthetic rate, $A$ - D) and dynamic of the instantaneous water use efficiency (WUE, $A / E$ 715 - E) measured on Salvia sinaloensis plants treated with full irrigation (100\% container capacity, 100\% 716 CC - black line), half irrigation (50\% CC - dark grey line), or no irrigation ( $0 \% \mathrm{CC}$ - light grey line).

717 Mean values showing the same letter are not statistically different at $P \leq 0.05$ according to the REGW-F 718 post-hoc test. The statistical relevance of 'Between-Subjects Effects' tests (ns=non significant, $*=P<0.05)$ was evaluated.

720

721 Fig. 3. Average values of growth index $\left(\right.$ G.I., $\left.\mathrm{cm}^{3}\right)$ during the experiment. S. sinaloensis plants were 722 treated with three irrigation regimes: full irrigation (100\% container capacity, $100 \% \mathrm{CC}$, black line), half 723 irrigation (50\% CC, dark grey line), or no irrigation (0\% CC, light grey line). Means superscripted by 724 the same letter do not differ significantly, according to REGW-F test $(\mathrm{NS}=$ non significant; $* \mathrm{P}<0.05$; $725 * * \mathrm{P}<0.001)$.

726

727 Fig. 4 Leaf total phenols (A) and flavonoids (B), and antioxidant activity (C) of Salvia sinaloensis plants 728 under control condition (black line, 100\% container capacity, CC), moderate drought stress (dark grey 729 line, 50\% CC), and severe drought stress (light grey, 0 \% CC). Means superscripted by the same letter 730 do not differ significantly, according to REGW-F test ( $\mathrm{NS}=$ not significant; $* \mathrm{P}<0.05$; ** $\mathrm{P}<0.001$ ). 
Ecophysiological and phytochemical responses of Salvia sinaloensis Fern. to drought stress

Matteo Caser $^{1 *}$, Francesca D'Angiolillo ${ }^{2}$, Walter Chitarra ${ }^{1,5,6}$, Claudio Lovisolo ${ }^{1}$, Barbara Ruffoni $^{3}$, Luisa Pistelli ${ }^{4}$, Laura Pistelli ${ }^{2}$, Valentina Scariot ${ }^{1}$

${ }^{1}$ Department of Agricultural, Forest and Food Sciences, University of Torino, Largo Paolo Braccini 2, 10095, Grugliasco (TO), Italy.

${ }^{2}$ Department of Agriculture, Food, and Environment, University of Pisa, Via del Borghetto 80, 56124, Pisa, Italy.

${ }^{3}$ CREA-OF, Ornamental Species Research Unit, Corso degli Inglesi 508, 18038, Sanremo (IM), Italy. ${ }^{4}$ Department of Pharmacy, University of Pisa, Via Bonanno 33, 56126, Pisa, Italy.

${ }^{5}$ Institute for Sustainable Plant Protection, National Research Council (IPSP-CNR), Strada delle Cacce 73, 10135, Torino (TO), Italy.

${ }^{6}$ CREA-VE, Viticulture and Enology Research Centre, Viale XXVIII Aprile 26, 31015, Conegliano (TV), Italy.

*Corresponding author: Matteo Caser, Department of Agricultural, Forest and Food Sciences, University of Torino, Largo Paolo Braccini 2, 10095, Grugliasco (TO), Italy, tel. +390116708935; fax +390116708798; mail: matteo.caser@unito.it 


\section{Supplementary files}

Supplementary Table 1. Chlorophyll $(a+b)$, total carotenoid (Car) and their rate (Chl:Car) measured on Salvia sinaloensis plants under full irrigation (100\% container capacity, CC), half irrigation $(50 \% \mathrm{CC})$, and no irrigation $(0 \% \mathrm{CC})$.

\begin{tabular}{|c|c|c|c|c|c|c|c|c|c|c|c|c|}
\hline & & \multicolumn{11}{|l|}{ Days } \\
\hline & & $\overline{0}$ & $\overline{4}$ & 7 & 11 & 14 & 18 & 21 & 25 & 28 & 32 & 34 \\
\hline \multirow{4}{*}{$\begin{array}{l}\text { Chl } a+b \\
(\mathrm{mg} / \mathrm{g} \mathrm{FW})\end{array}$} & $100 \% \mathrm{CC}$ & 1.40 & 1.49 & 1.43 & 1.38 & 1.35 & $1.50 \mathrm{a}$ & $1.32 \mathrm{a}$ & 1.36 & 1.42 & 1.43 & 1.45 \\
\hline & $50 \% \mathrm{CC}$ & 1.40 & 1.43 & 1.25 & 1.27 & 1.17 & $1.15 b$ & $1.15 \mathrm{~b}$ & 1.16 & 1.17 & 1.24 & 1.30 \\
\hline & $0 \% \mathrm{CC}$ & 1.40 & 1.39 & 1.44 & 1.42 & 1.38 & $1.13 b$ & $1.07 \mathrm{~b}$ & - & - & - & - \\
\hline & $P$ & $\mathrm{~ns}$ & $\mathrm{~ns}$ & $\mathrm{~ns}$ & ns & ns & $*$ & $*$ & $*$ & $*$ & $*$ & $*$ \\
\hline \multirow{4}{*}{$\begin{array}{l}\text { Car } \\
(\mathrm{mg} / \mathrm{g} \mathrm{FW})\end{array}$} & $100 \% \mathrm{CC}$ & 0.23 & 0.29 & 0.24 & 0.25 & 0.25 & 0.21 & 0.26 & 0.24 & 0.26 & 0.23 & 0.26 \\
\hline & $50 \% \mathrm{CC}$ & 0.23 & 0.22 & 0.21 & 0.24 & 0.20 & 0.16 & 0.18 & 0.19 & 0.24 & 0.24 & 0.23 \\
\hline & $0 \% \mathrm{CC}$ & 0.23 & 0.25 & 0.24 & 0.23 & 0.24 & 0.17 & 0.19 & - & - & - & - \\
\hline & $P$ & $\mathrm{~ns}$ & $\mathrm{~ns}$ & ns & ns & ns & ns & ns & $\mathrm{ns}$ & $\mathrm{ns}$ & $\mathrm{ns}$ & ns \\
\hline \multirow{4}{*}{ Chl:Car } & $100 \% \mathrm{CC}$ & 6.20 & 5.21 & 5.92 & 5.51 & 5.43 & 7.07 & 5.17 & 5.63 & 5.41 & 6.12 & 5.61 \\
\hline & $50 \% \mathrm{CC}$ & 6.20 & 6.54 & 5.86 & 5.24 & 5.97 & 7.35 & 6.45 & 6.25 & 4.97 & 5.15 & 5.76 \\
\hline & $0 \% \mathrm{CC}$ & 6.20 & 5.45 & 5.96 & 6.16 & 5.89 & 6.48 & 5.63 & - & - & - & - \\
\hline & $P$ & $\mathrm{~ns}$ & ns & $\mathrm{ns}$ & ns & ns & $\mathrm{ns}$ & $\mathrm{ns}$ & ns & $\mathrm{ns}$ & $\mathrm{ns}$ & $\mathrm{ns}$ \\
\hline
\end{tabular}

The statistical relevance of 'Between-Subjects Effects' tests $\left({ }^{*}=P<0.05, \mathrm{~ns}=\right.$ not significant). Mean values showing the same letter are not statistically different at $P \leq 0.05$ according to the REGW-F test.

Supplementary Table 2. Chemical composition (\%) of volatiles emitted from Salvia sinaloensis plants after full irrigation $(100 \% \mathrm{CC})$, half irrigation $(50 \% \mathrm{CC})$ or no irrigation $(0 \% \mathrm{CC})$. All constituents are ordered on the basis of their linear retention index (LRI).

\begin{tabular}{|c|c|c|c|c|c|}
\hline Category & Constituents & $\mathbf{I R I}$ & $100 \% \mathrm{CC}$ & $50 \% \mathrm{CC}$ & 0\% CC \\
\hline $\mathrm{mh}$ & $\alpha$-Pinene & 939 & 4.7 & 6.5 & 2.0 \\
\hline $\mathrm{mh}$ & Camphene & 953 & 2.6 & 6.6 & 2.6 \\
\hline $\mathrm{mh}$ & $\beta$-Pinene & 980 & 12.0 & 16.7 & 7.5 \\
\hline $\mathrm{mh}$ & Myrcene & 991 & 0.0 & 0.5 & 1.9 \\
\hline $\mathrm{mh}$ & Limonene & 1031 & 4.4 & 3.3 & 2.3 \\
\hline $\mathrm{mh}$ & (Z)- $\beta$-Ocimene & 1040 & 0.0 & 1.9 & 0.5 \\
\hline $\mathrm{mh}$ & $(E)$ - $\beta$-Ocimene & 1050 & 0.0 & 0.9 & 4.6 \\
\hline $\mathrm{mh}$ & Terpinolene & 1088 & 0.5 & 0.7 & 0.6 \\
\hline om & Trans-sabinene hydrate & 1097 & 0.0 & 0.5 & 0.7 \\
\hline om & Linalool & 1098 & 0.0 & 0.0 & 0.6 \\
\hline nt & 1-octen-3-yl-acetate & 1110 & 0.0 & 0.1 & 4.3 \\
\hline om & $\alpha$-Campholenal & 1125 & 0.0 & 0.0 & 0.4 \\
\hline om & Camphor & 1143 & 8.3 & 12.9 & 20.2 \\
\hline
\end{tabular}




\begin{tabular}{|c|c|c|c|c|c|}
\hline om & Borneol & 1165 & 1.4 & 2.2 & 0.7 \\
\hline om & $\alpha$-Terpineol & 1189 & 0.0 & 0.5 & 0.7 \\
\hline $\mathrm{nt}$ & $(N)$-decanale & 1204 & 0.0 & 0.1 & 0.6 \\
\hline om & Isobornyl acetate & 1285 & 0.0 & 0.1 & 0.7 \\
\hline sh & $\delta$-Elemene & 1339 & 1.4 & 0.6 & 0.2 \\
\hline $\mathrm{sh}$ & $\alpha$-Copaene & 1376 & 2.0 & 1.0 & 0.7 \\
\hline ac-13 & (E)- $\alpha$-damascenone & 1380 & 0.7 & 0.3 & 1.0 \\
\hline sh & $\beta$-Elemene & 1391 & 1.7 & 1.7 & 0.9 \\
\hline $\mathrm{sh}$ & Cyperene & 1398 & 0.6 & 0.5 & 0.6 \\
\hline $\mathrm{sh}$ & $\beta$-Caryophyllene & 1418 & 16.0 & 12.4 & 24.2 \\
\hline sh & $\beta$-Copaene & 1429 & 1.1 & 1.1 & 0.3 \\
\hline $\mathrm{sh}$ & $\beta$-Gurjunene & 1432 & 0.0 & 0.5 & 0.4 \\
\hline sh & $\alpha$-Guaiene & 1439 & 1.7 & 0.8 & 0.3 \\
\hline sh & $\alpha$-Humulene & 1454 & 3.9 & 3.5 & 6.5 \\
\hline $\mathrm{sh}$ & (E)- $\beta$-Farnesene & 1458 & 1.3 & 2.7 & 1.0 \\
\hline $\mathrm{sh}$ & $\alpha$-Himachalene & 1476 & 0.0 & 0.4 & 0.1 \\
\hline $\mathrm{sh}$ & $\gamma$-Muurolene & 1477 & 0.0 & 0.0 & 0.2 \\
\hline $\mathrm{sh}$ & Germacrene-D & 1480 & 22.0 & 12.1 & 5.0 \\
\hline sh & $\alpha$-Selinene & 1485 & 1.5 & 2.5 & 0.8 \\
\hline sh & Bicyclogermacrene & 1494 & 4.3 & 1.4 & 0.2 \\
\hline $\mathrm{sh}$ & Germacrene-A & 1503 & 0.0 & 0.3 & 0.2 \\
\hline sh & 7-epi- $\alpha$-selinene & 1517 & 0.0 & 1.3 & 0.7 \\
\hline sh & $\delta$-Cadinene & 1524 & 0.0 & 0.0 & 0.4 \\
\hline so & Caryophyllene oxide & 1581 & 0.0 & 0.0 & 0.5 \\
\hline \multirow[t]{8}{*}{ so } & $\alpha$-Cadinol & 1653 & 0.0 & 0.0 & 0.3 \\
\hline & Total & & 92.1 & 96.6 & 95.4 \\
\hline & Non Terpene Derivates (nt, \%) & & $\mathbf{0 . 0}$ & 0.2 & 4.9 \\
\hline & Monoterpene Hydrocarbons (mh, \%) & & 24.2 & 37.1 & 22.0 \\
\hline & Oxygenated Monoterpene (om, \%) & & 9.7 & 16.2 & 23.6 \\
\hline & Sesquiterpene Hydrocarbons (sh, \%) & & 57.5 & 42.8 & 42.7 \\
\hline & Oxygenated Sesquiterpene (os, \%) & & $\mathbf{0 . 0}$ & 0.0 & 0.8 \\
\hline & Apocarotenoids (ac, \%) & & 0.7 & 0.3 & 1.0 \\
\hline
\end{tabular}

*All the constituents identified belong to non terpene derivates (nt), monoterpene hydrocarbons (mh), oxygenated monoterpene (om), sesquiterpene hydrocarbons (sh), oxygenated sesquiterpene (os), and apocarotenoids (ac).

Supplementary Table 3. Effect of full irrigation (100\% CC), half irrigation (50\% CC) or no irrigation $(0 \% \mathrm{CC})$ on the essential oil constituents of Salvia sinaloensis plants. Constituents are ordered on the basis of their linear retention index (LRI).

\begin{tabular}{llllll}
\hline Category & Constituents & IRI & $\mathbf{1 0 0 \%} \mathbf{C C}$ & $\mathbf{5 0 \%} \mathbf{C C}$ & $\mathbf{0 \%} \mathbf{C C}$ \\
\hline $\mathrm{nt}$ & Hexenal & 800 & 0.2 & 1.0 & 0.0
\end{tabular}




\begin{tabular}{|c|c|}
\hline $\mathrm{nt}$ & $(E)$-3-hexen-1-ol \\
\hline $\mathrm{mh}$ & $\alpha$-Pinene \\
\hline $\mathrm{mh}$ & Camphene \\
\hline $\mathrm{mh}$ & Sabinene \\
\hline $\mathrm{nt}$ & 3-Octanone \\
\hline $\mathrm{mh}$ & Myrcene \\
\hline $\mathrm{nt}$ & 3-Octanol \\
\hline $\mathrm{mh}$ & Limonene \\
\hline om & 1,8-Cineole \\
\hline $\mathrm{mh}$ & $\gamma$-Terpinene \\
\hline om & Cis-sabinene hydrate \\
\hline $\mathrm{nt}$ & $(N)$-octanol \\
\hline om & Trans-linalol oxide (furanoid) \\
\hline om-no & Camphenilone \\
\hline $\mathrm{mh}$ & Terpinolene \\
\hline om & Linalool \\
\hline $\mathrm{nt}$ & 1-octen-3-yl acetate \\
\hline om & $\alpha$-Campholenal \\
\hline om & Trans-pinocarveol \\
\hline om & Camphor \\
\hline om & Isoborneol \\
\hline om & Pinocarvone \\
\hline om & Borneol \\
\hline om & 4-Terpineol \\
\hline om & Cymen8-ol-para \\
\hline om & $\alpha$-Terpineol \\
\hline om & Myrtenal \\
\hline om & Verbenone \\
\hline om & Trans-carveol \\
\hline om & Isobornyl formate \\
\hline om & Carvone \\
\hline om & Perilla aldehyde \\
\hline om & Isobornyl acetate \\
\hline $\mathrm{nt}$ & 2-undecanone \\
\hline $\mathrm{nt}$ & $(N)$-tridecene \\
\hline om & $\alpha$-Terpenyl acetate \\
\hline $\mathrm{nt}$ & Undecanol-N \\
\hline sh & $\beta$-Bourbonene \\
\hline ac-13 & $(E)$ - $\beta$-damascenone \\
\hline sh & Cyperene \\
\hline sh & $\alpha$-Gurujene \\
\hline
\end{tabular}

\begin{tabular}{|c|c|c|c|}
\hline 851 & 0.2 & 0.5 & 0.0 \\
\hline 939 & 0.0 & 0.5 & 0.1 \\
\hline 953 & 0.6 & 3.6 & 0.5 \\
\hline 976 & 0.4 & 1.2 & 1.0 \\
\hline 988 & 0.0 & 0.2 & 0.0 \\
\hline 991 & 0.0 & 0.3 & 0.1 \\
\hline 993 & 0.0 & 0.0 & 0.1 \\
\hline 1031 & 0.0 & 0.1 & 0.1 \\
\hline 1033 & 0.7 & 0.2 & 0.1 \\
\hline 1062 & 0.2 & 0.2 & 0.0 \\
\hline 1068 & 0.0 & 0.0 & 0.4 \\
\hline 1070 & 0.0 & 0.0 & 0.0 \\
\hline 1074 & 0.2 & 0.2 & 0.2 \\
\hline 1083 & 0.2 & 0.3 & 0.2 \\
\hline 1088 & 0.2 & 0.0 & 0.0 \\
\hline 1098 & 0.2 & 0.2 & 0.7 \\
\hline 1110 & 0.5 & 1.8 & 1.8 \\
\hline 1125 & 0.3 & 0.4 & 0.9 \\
\hline 1142 & 0.6 & 1.4 & 1.7 \\
\hline 1143 & 36.5 & 62.8 & 38.7 \\
\hline 1156 & 0.0 & 0.0 & 0.2 \\
\hline 1162 & 0.5 & 0.8 & 1.1 \\
\hline 1165 & 7.5 & 4.7 & 5.1 \\
\hline 1177 & 1.3 & 1.6 & 1.0 \\
\hline 1187 & 0.2 & 0.0 & 0.2 \\
\hline 1189 & 0.5 & 0.7 & 0.6 \\
\hline 1193 & 1.4 & 1.5 & 2.1 \\
\hline 1217 & 0.0 & 0.1 & 0.2 \\
\hline 1217 & 0.0 & 0.0 & 0.2 \\
\hline 1233 & 0.6 & 0.2 & 0.3 \\
\hline 1242 & 0.0 & 0.0 & 0.2 \\
\hline 1271 & 0.0 & 0.0 & 0.1 \\
\hline 1285 & 1.0 & 1.0 & 0.9 \\
\hline 1296 & 0.1 & 0.0 & 0.0 \\
\hline 1292 & 0.1 & 0.0 & 0.0 \\
\hline 1352 & 0.0 & 1.1 & 0.0 \\
\hline 1374 & 0.3 & 0.0 & 0.1 \\
\hline 1384 & 0.3 & 0.3 & 0.0 \\
\hline 1380 & 0.3 & 0.0 & 0.2 \\
\hline 1398 & 0.2 & 0.0 & 0.1 \\
\hline 1409 & 0.0 & 0.0 & 0.9 \\
\hline
\end{tabular}




\begin{tabular}{|c|c|c|c|c|c|}
\hline sh & $\beta$-Caryophyllene & 1418 & 1.5 & 5.7 & 8.3 \\
\hline sh & $\beta$-Gurjunene & 1432 & 0.5 & 0.0 & 0.0 \\
\hline sh & $\alpha$-Guaiene & 1439 & 0.5 & 0.0 & 0.0 \\
\hline sh & Aromadendrene & 1439 & 0.3 & 0.0 & 0.9 \\
\hline sh & $\alpha$-Humulene & 1454 & 0.2 & 0.0 & 0.1 \\
\hline ac-12 & Geranylacetone & 1453 & 0.0 & 0.0 & 0.2 \\
\hline sh & $(E)-\beta$-farnesene & 1458 & 0.0 & 0.0 & 0.2 \\
\hline sh & $\gamma$-Himachalene & 1476 & 0.2 & 0.0 & 0.0 \\
\hline sh & Germacrene-D & 1480 & 0.0 & 0.3 & 0.0 \\
\hline sh & $\beta$-Selinene & 1485 & 0.8 & 0.0 & 0.6 \\
\hline sh & Cis- $\beta$-guaiene & 1490 & 0.2 & 0.0 & 0.1 \\
\hline sh & Bicyclogermacrene & 1494 & 0.4 & 0.0 & 0.0 \\
\hline sh & Cuparene & 1502 & 1.2 & 0.3 & 0.2 \\
\hline sh & 7-epi- $\alpha$-selinene & 1517 & 1.0 & 0.2 & 0.5 \\
\hline sh & $\delta$-Cadinene & 1524 & 1.3 & 0.1 & 0.3 \\
\hline sh & $\alpha$-Calacorene & 1542 & 0.3 & 0.0 & 0.0 \\
\hline sh & Selina-3,7(11) diene & 1542 & 0.0 & 0.0 & 0.2 \\
\hline os & Elemol & 1549 & 0.3 & 0.2 & 0.8 \\
\hline os & Longicamphenylone & 1559 & 0.3 & 0.4 & 0.2 \\
\hline os & Trans-nerolidol & 1564 & 0.4 & 0.0 & 0.2 \\
\hline os & Spathulenol & 1576 & 1.9 & 0.5 & 1.6 \\
\hline os & Caryophyllene oxide & 1581 & 9.8 & 3.0 & 10.4 \\
\hline os & Cis- $\beta$-elemenone & 1594 & 0.4 & 0.1 & 0.2 \\
\hline os & Humulene oxide & 1606 & 0.8 & 0.3 & 1.3 \\
\hline os & 1,10-di-epi-cubenol & 1614 & 1.5 & 0.3 & 1.0 \\
\hline os & $\alpha$-Acorenol/g-Eudesmol & 1630 & 0.6 & 0.0 & 0.7 \\
\hline os & $\beta$-Acorenol & 1634 & 0.3 & 0.0 & 0.1 \\
\hline os & Epi- $\alpha$-cadinol & 1640 & 0.8 & 0.0 & 0.3 \\
\hline os & $\beta$-Eudesmol & 1649 & 0.2 & 0.0 & 0.2 \\
\hline os & $\alpha$-Cadinol & 1653 & 9.1 & 1.4 & 6.2 \\
\hline os & 14-hydroxy-9-epi-E-caryophyllene & 1664 & 1.6 & 0.0 & 1.6 \\
\hline os & Cis-14-nor-muurolen 5-en 4-one & 1682 & 0.9 & 0.1 & 1.4 \\
\hline os & $(E, E)$-Farnesol & 1722 & 0.2 & 0.0 & 0.2 \\
\hline os & 14-oxy-a-muurolene- & 1764 & 0.2 & 0.0 & 0.2 \\
\hline os & (Z)- $\alpha$-santalol acetate & 1786 & 0.0 & 0.0 & 0.4 \\
\hline \multirow[t]{6}{*}{ nt } & $(N)$-octadecane & 1800 & 1.5 & 0.0 & 0.1 \\
\hline & Total & & 94.0 & 99.6 & 98.8 \\
\hline & Non Terpene Derivates (nt,\%) & & 2.8 & 3.5 & 2.2 \\
\hline & Monoterpene Hydrocarbons (mh, \%) & & 1.4 & 6.0 & 1.9 \\
\hline & Oxygenated Monoterpene (om, \%) & & 51.5 & 77.1 & 54.9 \\
\hline & Sesquiterpene Hydrocarbons (sh, \%) & & 8.8 & 6.8 & 12.4 \\
\hline
\end{tabular}


Oxygenated Sesquiterpene (os, \%)

*All the constituents belong to non terpene derivates (nt), monoterpene hydrocarbons (mh), oxygenated monoterpene (om), sesquiterpene hydrocarbons (sh), oxygenated sesquiterpene (os), and apocarotenoids (ac). 